Markus Jäntti
Olli Kangas
Veli-Matti Ritakallio

FROM MARGINALISM TO INSTITUTIONALISM: distributional consequences of the transformation of the

Finnish pension regime

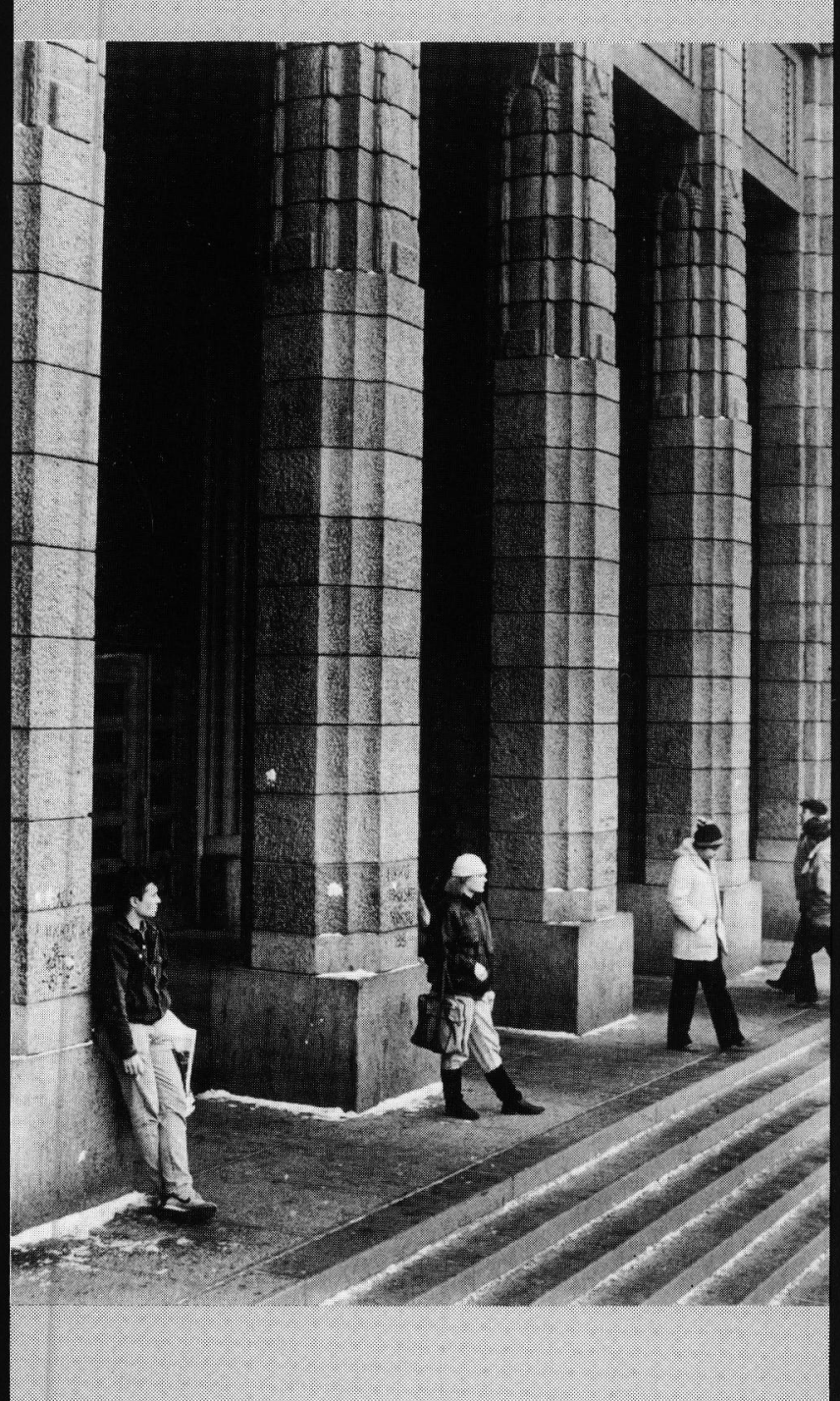

(18) THE CENTRAL

Studies 1995:5 


\title{
FROM MARGINALISM TO INSTITUTIONALISM: distributional consequences of the transformation of the Finnish pension regime
}

\author{
by
}

Markus Jäntti Department of Economics Ábo Academy University SF-20500 Ábo, Finland

\&

Olli Kangas

Department of Social Policy

University of Turku

SF-20500 Turku, Finland

\&

Veli-Matti Ritakallio

Department of Social Policy

University of Turku

SF-20500 Turku, Finland 
ISBN 952 - 9639 - $33-3$

ISSN 1236 - 3049

PAINATUSKESKUS OY, HELSINKI 1995

Kannen kuva P Nisonen/Gorilla 


\section{ABSTRACT}

The recent social policy discourse has revitalized Richard Titmuss' famous distinction between three ideal types of the welfare state: the marginal, industrial achievement, and institutional models. "From marginalism to institutionalism" offers a longitudinal scrutiny of the development of pension policy in Finland and evaluates the impacts that the shift from 'marginal' social policy to the 'institutional' welfare state imposed on economic wellbeing and income distribution among the elderly. Data used are derived from household budget surveys from 1966, 1971, 1976, 1981, 1985, and 1990.

The study shows that between 1966 and 1990, average income of a retired household doubled in real terms. During that period statutory pensions replaced earnings, private pensions, and income from capital and self employment as the most important components in the income package of the elderly. The shift from marginalism to institutionalism has changed the traditional cycle of poverty, where the elderly have a significantly higher risk of being poor. Up to the early seventies, the risk of poverty increased with age but improvements in pension security gradually mitigated the poverty risk and by 1990 differences between different age groups are small. The same trends emerge in the development of inequality. By 1990, poverty and income inequalities among the Finnish elderly are by international standards rather low. 


\section{CONTENTS}

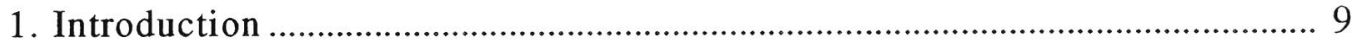

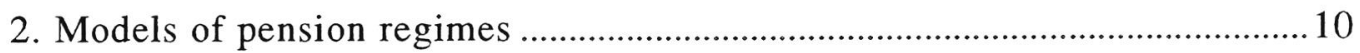

3. The transformation of the Finnish pension regime .........................................14

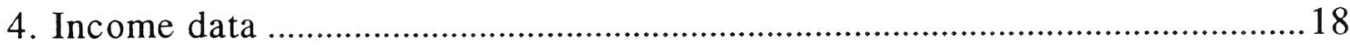

5. The composition of the income package …….............................................. 19

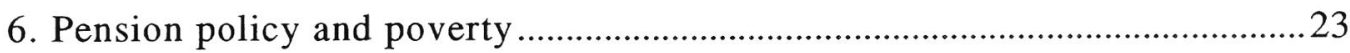

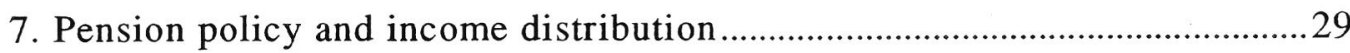

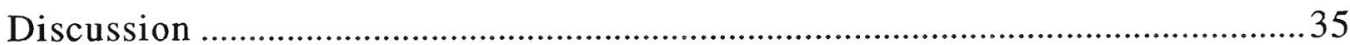

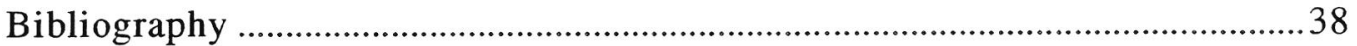

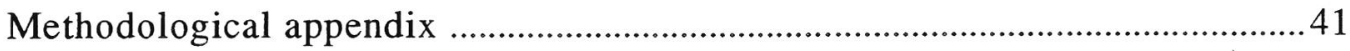




\section{Introduction}

In his book "Social Policy", Richard Titmuss (1974) made a famous distinction between three ideal types of the welfare state: the marginal, industrial achievement, and institutional models. Recent social policy discourse has revitalized this trichotomy. The revitalization can be seen in two partially overlapping areas. First, researchers have tried to unravel the way in which advanced welfare states cluster in terms of their social policy solutions (e.g., Esping-Andersen 1990; Castles \& Mitchell 1990; Kangas 1994). Second, the possibilities offered by a number of comparable databases, especially by the Luxembourg Income Study (LIS), have stimulated numerous studies of the distributional consequences of different ideal types of social policy (see e.g., Smeeding, O'Higgins \& Rainwater 1990; Fritzell 1991; Mitchell 1991; Ritakallio 1994a).

Empirical analyses of the consequences of different welfare state models have mainly been based on cross-sectional comparisons of a number of advanced OECD countries. Although cross-sectional comparisons reveal important links between institutional solutions and their distributive effects, they do not necessarily untangle the dynamics or the development of the mechanisms behind these links. Therefore, in addition to careful cross-national analyses, we also need more detailed longitudinal studies of the developmental patterns within single countries.

The purpose of this paper is to offer such a longitudinal scrutiny of the development of social policy in one country, i.e., Finland. Until the early 1960s, Finland was a welfare state laggard, but by 1990 it provided citizens with social protection that can be considered high by international standards. 
Thus, the development of the Finnish welfare state offers an interesting test case for evaluating the impacts of a shift from 'marginal' social policy to the 'institutional' welfare state imposed on economic well-being and income distribution. Due to space limitations, we concentrate our analysis on one area of outcomes. Here, we are especially interested in the development of poverty and income inequality among the elderly. Moreover, we will analyze the interplay of public and private components in old-age security. Has the improvement of legislated pensions crowded out occupational pensions and other "private" sources of income? What about the trends in the distributive effects of different sources of income?

The structure of the paper is as follows: First, we briefly review some classifications or ideal types of pension policy. The third section outlines the general development and institutional changes in Finnish pension policy. In other words, the section is focussed on the shift from marginalism to institutionalism. Thereafter we describe the longitudinal database used. The fifth section analyses the shifts that have occurred since the mid 1960s in the income package provided for the elderly. The two following sections inspect the distributional effects of the transformation of the pension regime: first in terms of poverty among the elderly and then in terms of income inequality. A concluding section summarizes and discusses future prospects in the light of the findings.

\section{Models of pension regimes}

In characterizing the three welfare state models, Titmuss (1974) was not too explicit in his typology, and numerous clarifications of the models have therefore since been suggested (Korpi 1980; Mishra 1981; Esping-Andersen 
1990; Castles \& Mitchell 1990). Of special interest for the present study is Palme's (1990a, see also Palme 1990b) classification, tailored for analyzing pension policy. In his study of the development of pension security in 18 OECD countries, Palme clusters pension systems on the basis of two dimensions: to what extent different welfare states guarantee (1) basic security and (2) income security, i.e., income-related pensions. The goal is to classify countries according to the relative importance of these two entitlement principles attached to pension policy. The classification leads into the following four-fold table.

Table 1. Models of pension security.

\section{Basic security}

\begin{tabular}{|c|c|c|c|}
\cline { 3 - 4 } \multicolumn{1}{c|}{} & No & No & Yes \\
\cline { 3 - 4 } \multicolumn{1}{c|}{$\begin{array}{l}\text { Income } \\
\text { security }\end{array}$} & Yesidual & $\begin{array}{c}\text { 2. Basic security } \\
\text { model }\end{array}$ \\
\cline { 2 - 4 } & Yes & $\begin{array}{c}\text { 3. Income } \\
\text { security model }\end{array}$ & $\begin{array}{c}\text { 4. Institutional } \\
\text { model }\end{array}$ \\
\hline
\end{tabular}

In the 'residual' model (in Titmuss' terminology 'marginal'), the state guarantees neither basic security nor income-related benefits. This may be due to an inadequate level of minimum benefits, and/or to limited coverage of social security. Usually, targeted means-tested benefits that limit the scope of coverage have been regarded as a trademark of the residual model of social policy. 
In the 'basic security' model, a more or less satisfactory minimum standard is guaranteed to the whole population. Thus, the basis for entitlement is citizenship and/or registered residence in the country concerned. Because of the lack of income-related state benefits, the role of occupational pensions and other "private" income sources in these two models is supposed to be important, Those, whose labor market position is strong enough, obtain income-security through collective bargaining or through individual insurance policies.

Palme labels his third ideal type the 'income security' model (Titmuss' 'industrial achievement' model). The emphasis in this model is on guaranteeing generous income-related social protection to those who are in paid work, whereas those working at home without pay receive very scanty benefits, if any.

The fourth, 'institutional' model combines basic security for everybody and income-related benefits to the economically active. Consequently, eligibility for social protection is based both on citizenship and on work-merit. Because of the high degree of need-satisfaction provided by the statutory schemes in this model, the scope of market-based programs is presumed to be limited.

The debate on the distributional impacts of pension policy models seems to be a highly contested terrain, and widely diverging opinions have been presented. According to one strand of debate, the means-tested model is the most egalitarian, since it is biased in favor of the worst-off: it distributes from the rich to the poor. The means-tested model is not only the most egalitarian, but also the most efficient way to channel resources. By targeting benefits to the most needy, the spill-over effect of welfare provisions to wealthier strata is 
eliminated. But here lurks the greatest problems of the model, as well. The means-tested model may run into a legitimation crisis, as those who finance the schemes are excluded from the benefits. Moreover, means-tested benefits tend to create disincentives, by punishing those responsible members of the community who have taken care of themselves.

As a solution to the incentive and legitimation problems, some scholars and politicians speak in favor of the basic security model, where universal flat-rate pensions are guaranteed to everybody. The advocates of the basic security model are critical of the income-related pensions, which are blamed for reproducing inequalities and status differences that stem from the labor market.

Finally, the supporters of the institutional model emphasize the merits of combining basic security with income security. The basic pension component guarantees a decent livelihood for those with no or sparse work history, while legislated income-related components provide equal pensions to the entire working population. In the latter aspect, a central question is the equal treatment of different employment categories. Advocates of this model claim that despite income-graduation, statutory pensions increase inequality by providing workers with rights that are similar to those granted by labor market contracts, occupational pension schemes, and individual pension policies to certain categories of salaried staff.

Hypotheses on the distributional consequences of the four pension regimes have been evaluated using cross-national comparisons, usually utilizing the data base compiled by the LIS (see e.g., Whiteford 1993; Korpi \& Palme 1994). Cross-national comparisons have often been criticized for merely revealing associations between phenomena, rather than exposing the more interesting causal mechanisms that produce such associations. The purpose of 
this paper is to complement the picture given by cross-national analyses by providing a longitudinal assessment of the distributional consequences of a transformation of the pension regime.

\section{The Transformation of the Finnish Pension Regime}

Finland was a late-comer in pension policy (for a general review, see Salminen 1993). The first pension act came into effect in 1939 -- of the current OECD member countries only Switzerland and Japan lagged behind. In principle, the Finnish national pension scheme of 1939 was universal in its coverage, but in practice means-testing and other qualifying conditions excluded the majority of the elderly from benefits. By 1950, only one fifth of the elderly above the normal pension age of 65 years were entitled to national pensions (Kangas \& Palme 1992, 202). In other words, the take-up ratio was extremely low. Also, the benefits provided were meager. With all possible supplements, the full national pension amounted to no more than 15 percent of the average industrial wage ${ }^{1}$, which was one of the lowest replacement rates in the Western countries (SCIP). Thus, early Finnish pension security was clearly residual in character.

Finnish national pension legislation was totally revised in 1956. The new National Pension Act achieved universalism, whereby everybody who was older than 65 years became automatically eligible to a national pension. Citizenship became the basis for entitlement. More specifically, the national pension was divided into two separate parts: a basic amount, paid on the basis of citizenship or residence of at least 5 years, and an income-tested

\footnotetext{
${ }^{1}$ However, there were some privileged groups. All civil servants and some salaried employees in the private sector were guaranteed by occupational pensions.
} 
supplement. Compared to the other Scandinavian countries, the universal and unconditional basic amount has been rather low in Finland, varying between 5 percent and 10 percent of the average industrial wage (Figure 1). Until 1985, any other income proportionally decreased the claimant's supplement amount. In 1985, income-testing was relieved, and since then only employmentrelated pensions cause decreases in the supplement amount. That is, the previously income-tested national pension became pension-income tested.

Figure 1. Minimum pension net-replacement rate in Finland 1950-1990, \% of average net wage.

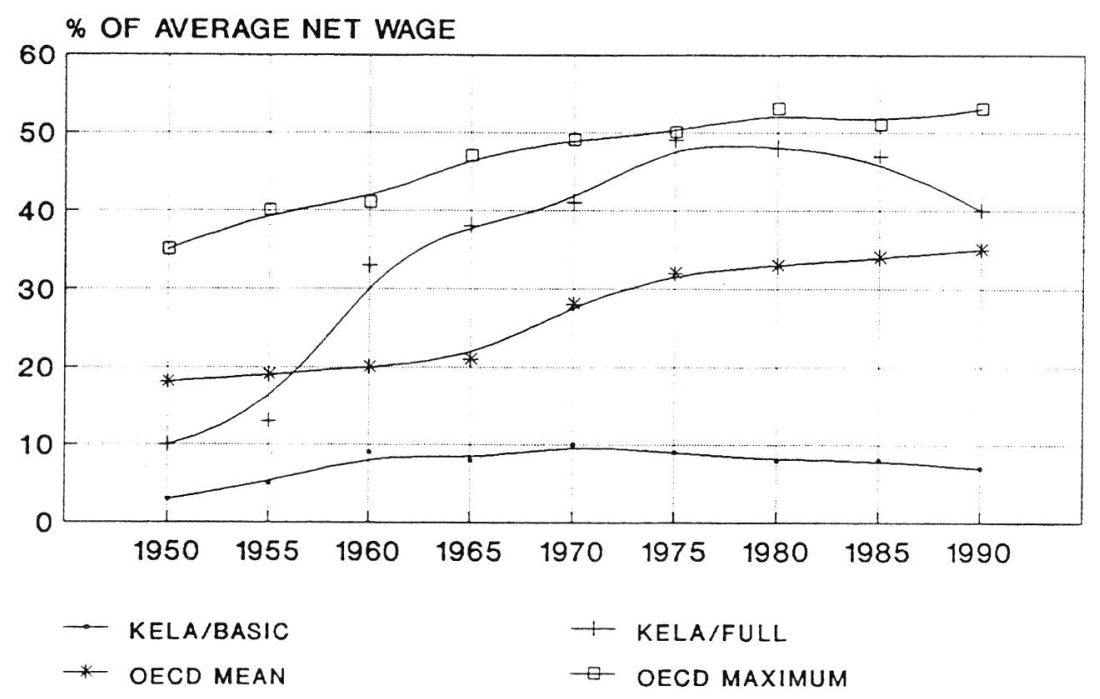

In the 1950s, the Finnish pension regime was residual in its character. Due to the improvements carried through in the late fifties and early sixties, the regime gradually shifted from residualism toward the basic security model. In the early 1960s, the basic pension (national pension basic amount, plus the full supplement) payable to pensioners without other income was 35 percent of the average industrial net wage. In 1970 it corresponded to 40 percent and in 1975 50 percent of the average wage (Figure 1). During the booming economy of the 1980s, basic pensions could not keep up with the rise in the average 
income, and consequently, the replacement rate declined ten percentage points (from 49 percent of the average net wage in 1980 to 38 percent in 1990). Thus, the basic security guaranteed to those outside the labor market and paid work - mostly home-making women -- deterioratedin relative terms.

From the mid-1960s, a gradually growing work-merit element was added to the basic security model. The legislation introducing an income-related pension scheme (TEL) for private-sector employees and a separate system for casual workers (LEL) was passed in 1961 (effective from 1st June, 1962). When TEL and LEL were implemented, the existing state (VEL) and municipal pension systems (KVTEL) remained intact, and the private-sector legislated scheme was built up separately. Thus, in addition to TEL and LEL, there are separate income-related pension schemes for public-sector employees. In the beginning of the 1970 s, separate superannuation programs were also introduced for farmers and other self-employed categories and by this time the total Finnish labor force had become covered by statutory income-graduated pensions whose income replacement ratio has hovered around the OECD mean (Figure 2).

There are some important differences between statutory pension rights in the private and the public-sector, and these differences may generate significant differences in the distributional profiles of the various schemes. First, the pension scheme for state employees was codified in 1925. Therefore, the public-sector pension system is now "mature", and full benefits can be paid out, whereas the TEL-scheme is still gradually maturing (by 1.5 percent per year) and the first full TEL-pensions will be paid out only in the year 2002 . The difference between "mature" public sector pensions and "maturing" TELpensions can be seen in Figure 2. The gap between the privileged civil servants and the less fortunate private-sector workers has been made up by the gradual 
improvements in TEL-benefits. Second, the target level has been lower in the private sector scheme: 60 percent of the final gross wage after 40 years in employment (accumulating pension rights by 1.5 percent per year) compared to 66 percent after 30 years in the public-sector (accumulating pension rights by 2.2 percent per year). According to current legislative amendments, publicsector employees' pensions are to be gradually decreased to a level identical with private-sector TEL-benefits.

Figure 2. Replacement rates in work merit pensions in Finland 1950-1990, \% of previous net wage.

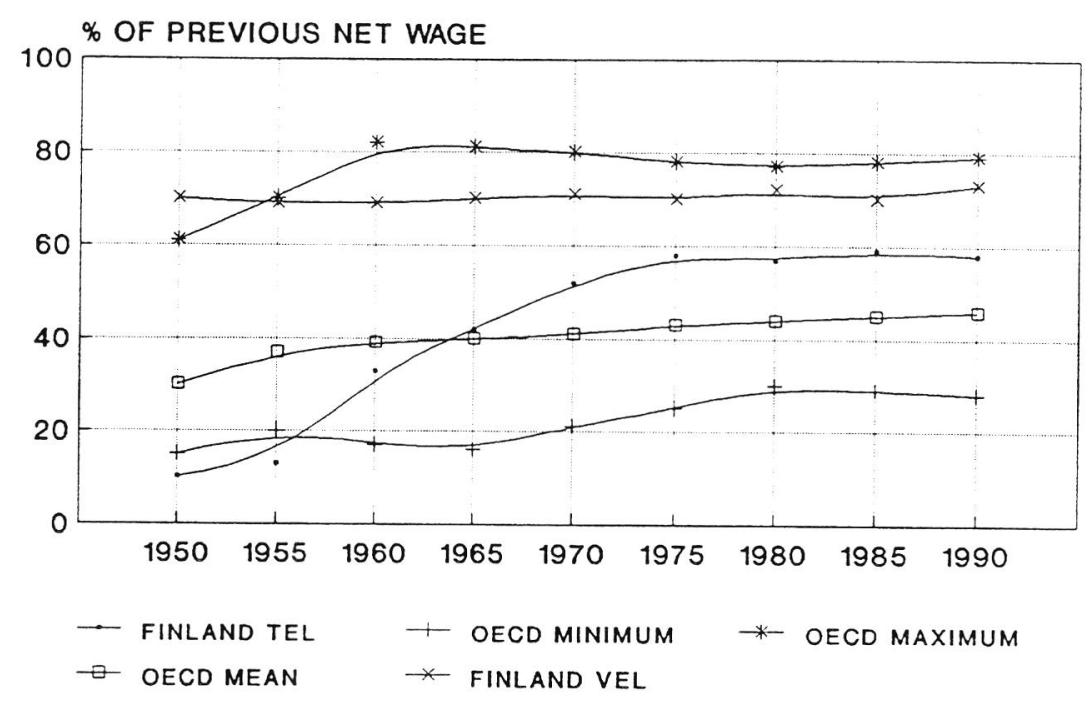

In sum, the combination of basic security with elements of the income security model gradually transformed the Finnish pension regime to the institutional model (see also Palme 1990, 91). The subsequent sections review the distributional consequences of this transformation. 


\section{Income data}

Our empirical analyses of distributional consequences of the shift in the pension regime are based on the Finnish household budget surveys (HBS) that are representative of the whole population. The Central Statistical Office has conducted these surveys at five year intervals 1966 (for a closer description, see Uusitalo 1989). The household budget surveys provide data on incomes and expenditure in Finland in 1966, 1971, 1976, 1981, 1985, and 1990. Data are partially derived from interviews, and, since the 1971 survey, increasingly also from official registers. Income data are collected from tax and other registers and are generally considered to be of high quality.

The basic unit in HBS is the household. The sample size varies from 4471 households in 1966 to 8258 households in 1990. In order to weight the samples to the population level, certain adjustments have been made. First, since incomes of households of different sizes are hard to compare, we increase comparability by weighting incomes by equivalence scales (see, e.g., Smeeding \& al. 1985, 50; Hedström \& Ringen 1990, 89-91; Fritzell 1991, 4951). In this study, we have chosen to divide the aggregate household income by the so-called OECD-equivalence scale, whereafter this "individual" equivalence income is multiplied by the number of members in each household in the sample. For example, in 1990, the application of this procedure produces data of 22627 cases. Finally, these sample data are then multiplied to the level of the total population by special weights included in the household surveys.

Although there are the usual survey problems with non-response, the underrepresentation of certain forms of income (income from self-employment, property income, and received transfers), HBS offers the most reliable standardized data set for analyzing the impacts of social changes. The repeated 
nature of the surveys enables us to simulate a panel design and to better evaluate the consequences of the improvements in pension security. Strictly speaking, the approach is not a panel study, since data are not collected from the same respondents at different points in time. Rather, we have applied the so-called trend approach, where data are derived from the same population but not from the same individuals (Hagenaars 1990, 17-19). The units are thus cohorts, which are followed over time. Although the trend approach is less powerful than the panel design, it is powerful enough for reliable analyses of distributional effects of the transformation of the Finnish pension regime from the basic security model to the institutional regime (from box 2 to box 4 in Table 1).

\section{The composition of the income package}

In all societies, people seek shelter from the uncertainties of life. In industrialized societies, social policy is an institutionalized form of collective protection against social risks. In addition to statutory social policy, individuals can also rely on markets and the informal sector. The assemblage of income from the different arenas constitutes the income package of an individual or a group of individuals (Rainwater, Rein \& Schwartz 1986, 12 24). In their income package, the elderly can mix income from various sources: from paid work, self-employment, savings, investments, social security, and occupational or private insurance policies.

The relative importance of the different components in the income package of the elderly vary considerable between countries and may change over time. In order to get a fuller picture of the developmental patterns of the economic 
well-being of the Finnish elderly, we therefore analyze the development of the entire income package, not only the public pensions.

The discussion above indicates that social policy is not developed in an institutional vacuum, but rather that existing institutional arrangements precondition the subsequent policy options available. This institutional environment affects the choices of individuals and corporate social actors, and there are several theories and research findings exploring the institutional interplay between the components of the income package. For example, it is assumed that if the statutory pension schemes are of poor quality, people will acquire individual insurance policies and/or collectively negotiate occupational benefits with their employers. The converse of this hypothesis predicts that improving statutory social security will gradually crowd-out private schemes. Indeed, some earlier cross-sectional studies on pension policy display a certain crowding-out effect between statutory benefits and private arrangements: the better the public scheme, the less important are private arrangements (EspingAndersen 1990; Kangas \& Palme 1992). However, some other studies, based on longitudinal data, report a simultaneous growth and co-existence between different parts of the income package (Griffin 1992, 92). Instead of the crowding-out effect, parallel growth is posited (Kuhnle \& Selle 1990).

Figure 3 displays the development of the income package of the Finnish elderly. The income package of the elderly is decomposed into eight different sources of income: national pensions, private and public sector employment pensions, other transfers from the public sector, private occupational pensions, work income, income from self-employment and capital income. 
Figure 3. The development of the average income package of the Finnish eldery, 1966-1990 (in 1990 prices).

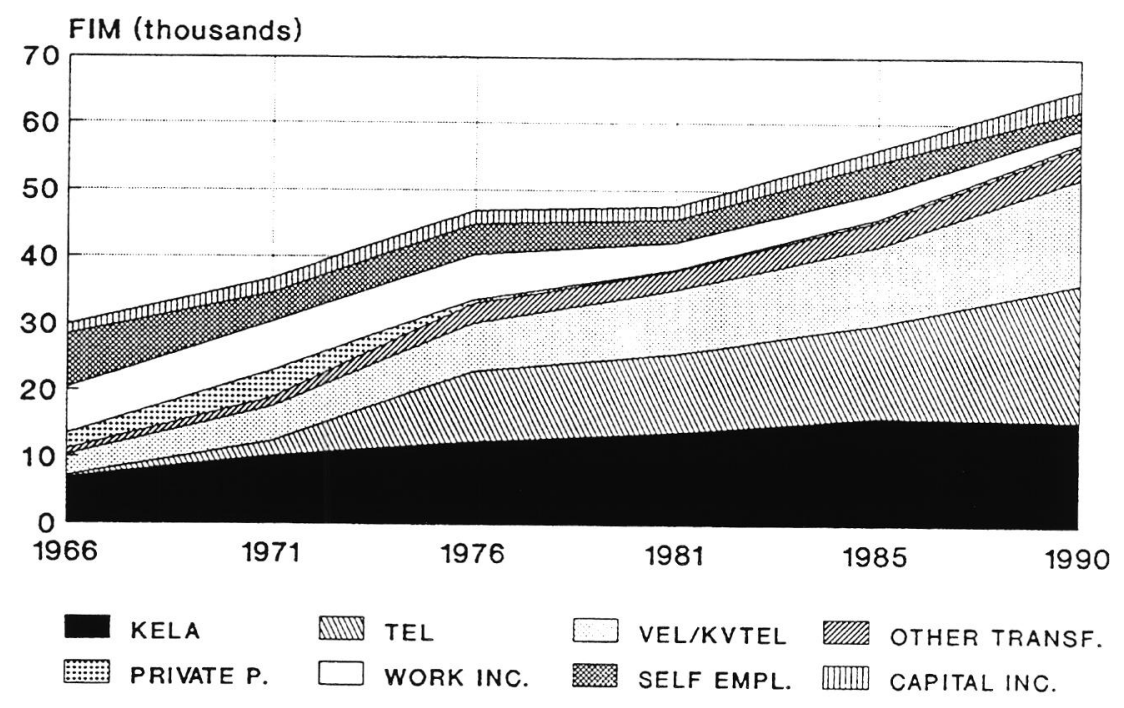

Figure 3 shows that between 1966 and 1990, average income doubled in real terms (current prices are adjusted by the consumer price index). Income from the national pension scheme (KELA) has been rather stable throughout the period, whereas from 1971 onwards a rapid growth took place in the private (TEL) and public-sector employment-related pensions (VEL/KVTEL). Also other transfers from the public sector -- mainly housing allowances -- show a slight increase, whereas in real terms income from work and occupational pensions have decreased. Thus, the average pensioners owe the improvements in their real income to income-related pensions.

In Figure 4 the development of the income package is shown from a different point of view: instead of the absolute changes, this figure focuses on the relative importance of the different components. As can be seen in the figure, striking shifts have taken place. In 1966, statutory pensions constituted only one third of the income package, while work and self-employment were the most important sources of old-age security. By 1990, the role of earnings and 
self-employment is marginal: they comprise only 8 percent of the income package. The drop in the relative importance of earnings can mainly be explained by improvements in the statutory income-graduated pensions (TEL, VEL, KVTEL), which contribute 65 percent to the total income package. The rapid transformation of the economic base of Finnish society from agriculture to industry and services lies behind the steady decline in income from selfemployment.

Figure 4. Components of average income package of the Finnish eldery, 19661990.

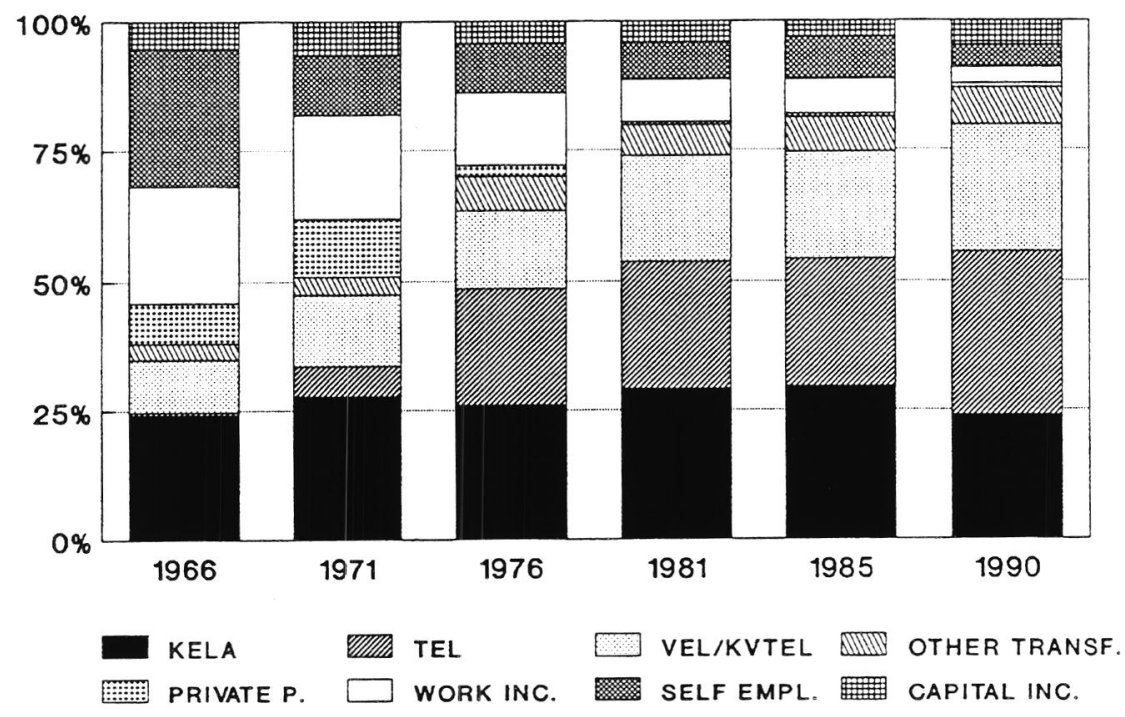

Both figures 3 and 4 are clearly consistent with the crowding-out hypothesis. The improvements in legislated pensions have gradually eroded the importance of additional occupational arrangements. In 1966, the contribution of occupational pensions to the income package was almost ten percent, whereas in 1990 it was less than one percent. This crowding-out trend in Finland contradicts the developments in many other countries over the same period, where a growth in occupational benefits is visible (see e.g. Kangas \& Palme 
1992). For example, in the United Kingdom occupational pensions increased in importance from 14 percent in 1971 to 23 percent in 1988 (Griffin 1992, 93).

These diverging trends in private occupational pensions in different countries reflect differences in the institutional set-ups for statutory pensions. In these set-ups, there is one Finnish peculiarity which distinguishes Finland from the other OECD countries. In contrast to the other countries, there are no pension ceilings (maximums) in the Finnish statutory income-related schemes. The target level is 60 percent or 66 percent of the final wage or salary, irrespective of its size. This implies that high-income earners have had little incentive to establish separate supplementary programs, and the occupational pension schemes that were established before the implementation of statutory earnings-related pensions have thus been gradually replaced by the statutory schemes (see Kangas \& Palme 1992).

\section{Pension policy and poverty}

Although everybody has some idea what poverty means, the concept of poverty and the measurement of poverty is a highly contested terrain among social scientists (see e.g. Alcock 1993; Jäntti 1993, 15-40). Researchers have proposed a wide variety of different measures, ranging from the absolute minimum food-intake line to more or less relative definitions (Ringen 1987, 141-165). Often, different definitions produce different pictures of the scope and extent of poverty. For example, in his study of poverty in Finland, Ritakallio (1994b, 42-45) found out that a relative measure based on low income tends to identify quite different groups of person as poor either than a measure based on expenditure on goods and services, or than a measure based 
on recipiency of social assistance. The overlap between these three measures is strikingly poor.

In principle, our data would allow us to apply all three measures, but since we are primarily interested in the income package, we have defined poverty in terms of low income. We apply the commonly used head-count ratio, which expresses the proportion of the poor in the total population. According to this measure, the poor are persons belonging to a family with equivalent net income below a certain percentage, in our case 50 percent, of the median income for the whole population.

In order to get an overview of the dynamics producing old-age poverty, we have first studied poverty in different age groups within the elderly (Figure 5) at different points in time. Figure 5 shows that up to the early seventies, the risk of poverty increased with age. For example, in 1971 the poverty rate in the age bracket 50-54 years was 8 percent, compared to 18 percent among those above 75 years of age. Gradually, improvements in pension security mitigated the poverty risk among those above the normal pension age of 65 years. By 1990, differences in the poverty risks between the age groups had become minimal. In sum, the shift of pension regime described in Figures 1 and 2 seems to have considerably changed the traditional cycle of poverty, where the elderly have a significantly higher risk of being (permanently) poor. 
Figure 5. Poverty in Finland among the eldery age groups, 1966-1990 (poverty line $=50 \%$ of the median income).

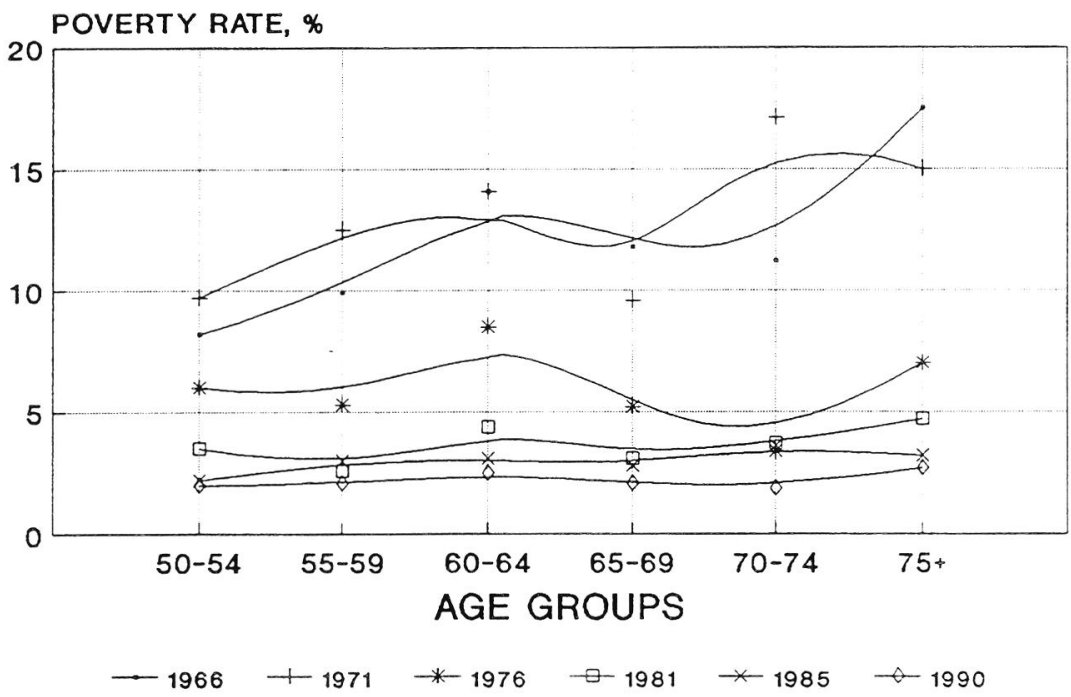

Figure 5 gives us six cross-sectional snapshots of the material well-being of six age groups in Finland. The problem with cross-sectional studies is that we cannot fully capture the dynamics operating between old-age poverty, the improvements in pension security and getting older in different generations. The cross-sectional age group differences that we have observed in previous figures can be interpreted as differences between cohorts or generations only if the generational characteristics are stable over time (Hagenaars 1990, 17). This is hardly the case. As described above, the Finnish employment-related pensions for private sector employees were implemented in 1962. Since then, pensions have been maturing by 1.5 percent a year. This means that different cohorts have not had equal possibilities to accumulate their pension rights. Older cohorts retiring in 1966 usually had TEL pension rights accumulated from only five years, and thus their income-related pensions amounted to 7.5 percent of wage, whereas cohorts that retired in 1990 had accumulated their TEL pension rights over 29 years, and their income-related pension could 
correspond to 43.5 percent of their final wage or salary. This clearly indicates that there are indeed very strong generational effects. Our database allows us to combine a series of trend studies to for a simple cohort design to unravel how different cohorts with diverging pension rights are exposed to poverty.

In Figure 6, we apply 50 percent of the median poverty line to cohorts defined by age brackets of five years. The oldest cohort comprises those who were born between 1912 and 1916. In 1966 they belonged to the age group aged 50 to 54 years, and in 1990 they were 75 or over. For this cohort, we have six observations, which means that the cohort has passed through all our six age groups. For the youngest cohort, born between 1937 and 1941, data are displayed in only one age bracket (50-54 years of age).

The general pattern (with minor exceptions) displayed in Figure 6 is that each cohort ends up with a lower poverty rate than the previous one. In other words, each subsequent cohort has enjoyed higher material well-being than its forerunners.

Figure 6. Poverty in Finland among different cohorts.

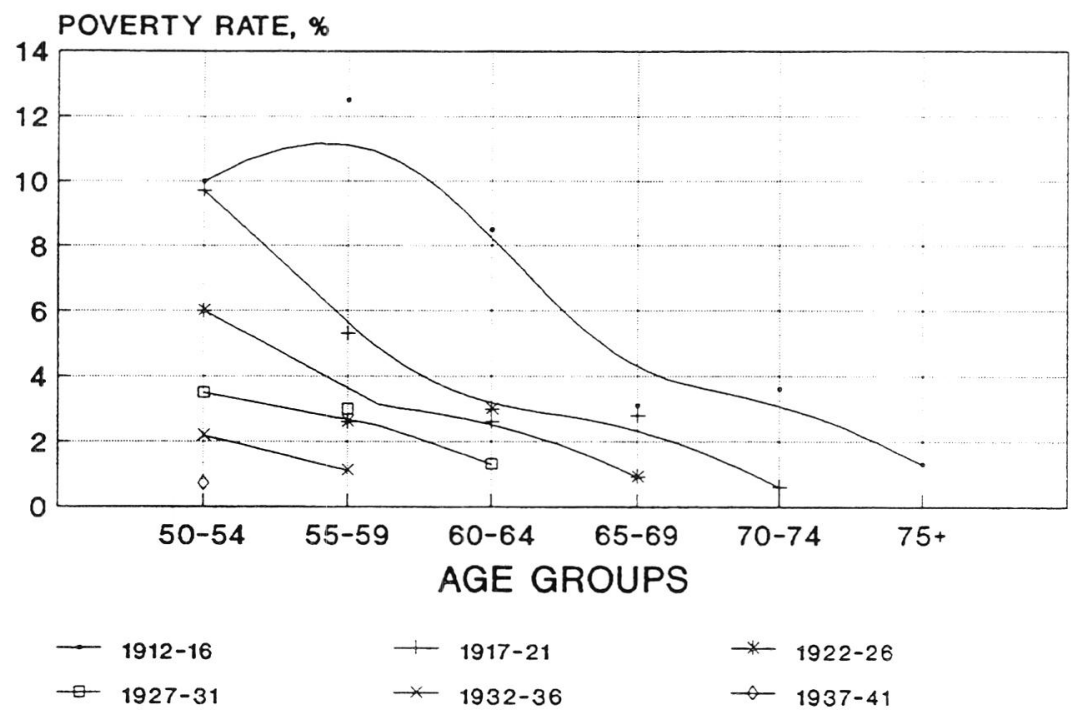


In the previous figures the poverty line was defined as 50 percent of the national median. In order to check the sensitivity of our measure, we also used two other poverty lines, namely 40 percent and 60 percent of median income. As can be seen in Figure 7, the story told by the different measurement levels is quite similar: poverty among the Finnish elderly has dramatically diminished from 1966 to 1990. According to the 40 percent level, the proportion of poor pensioners fell from 14.2 percent in 1966 to 0.5 percent in 1990. By the mid sixties, only 22.2 percent of the elderly had income below half of the national median. In 1990, the corresponding figure was $4.2^{2}$. The highest poverty line classifies 36.6 percent of the elderly in 1966 as being in poverty, and 15.2 percent in 1990.

Figure 7. Poverty among the Finnish eldery according to three poverty lines, 1966-1990.

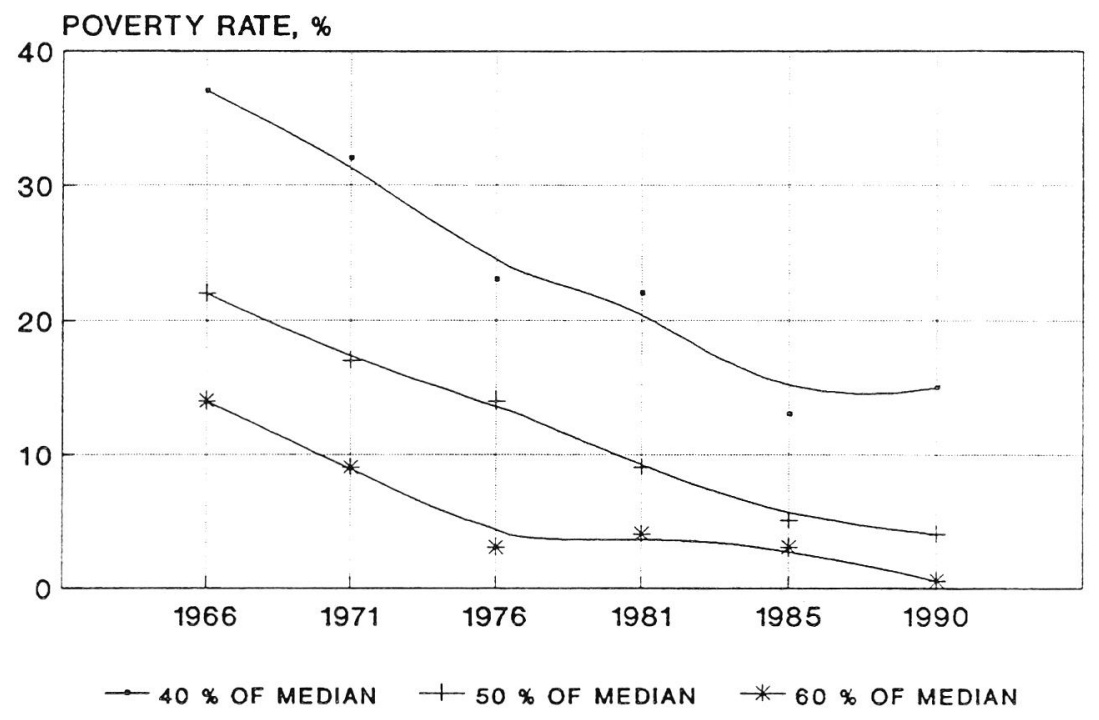

\footnotetext{
${ }^{2}$ In the mid-1980s, the Finnish poverty rate according to the 50 percent line was 5.0 percent. The corresponding figures for the U.S.A., Australia, Germany, and Sweden were 17.2, 6.0, 5.7, and 1.4 percent, respectively (LIS data files).
} 
The comparison of Figures 1 and 7 shows partially contradictory trends in Finland. According to Figure 1, since the mid-seventies the national pension level in relation to average earnings has steadily deteriorated. Despite this, the poverty rate among the elderly has declined. The explanation for these apparently diverging patterns can be found in the maturation of the incomerelated pension schemes. More and more pensioners receive income through these schemes. In addition, each new cohort accumulates better income-related pensions, compensating for the drop in basic pensions. Thus, the income level of the elderly population as a whole may increase, even though the relative income level of those living on national pensions only may decrease.

It is interesting in this respect to compare poverty rates among elderly women and men. Since the labor force participation of men has been higher, and those without work records are more often women, we might predict that a deterioration of the national pension would hit women first. For men the drop in national pensions is compensated through earnings-related benefits.

Figure 8. Poverty among the eldery males and females, 1966-1990.

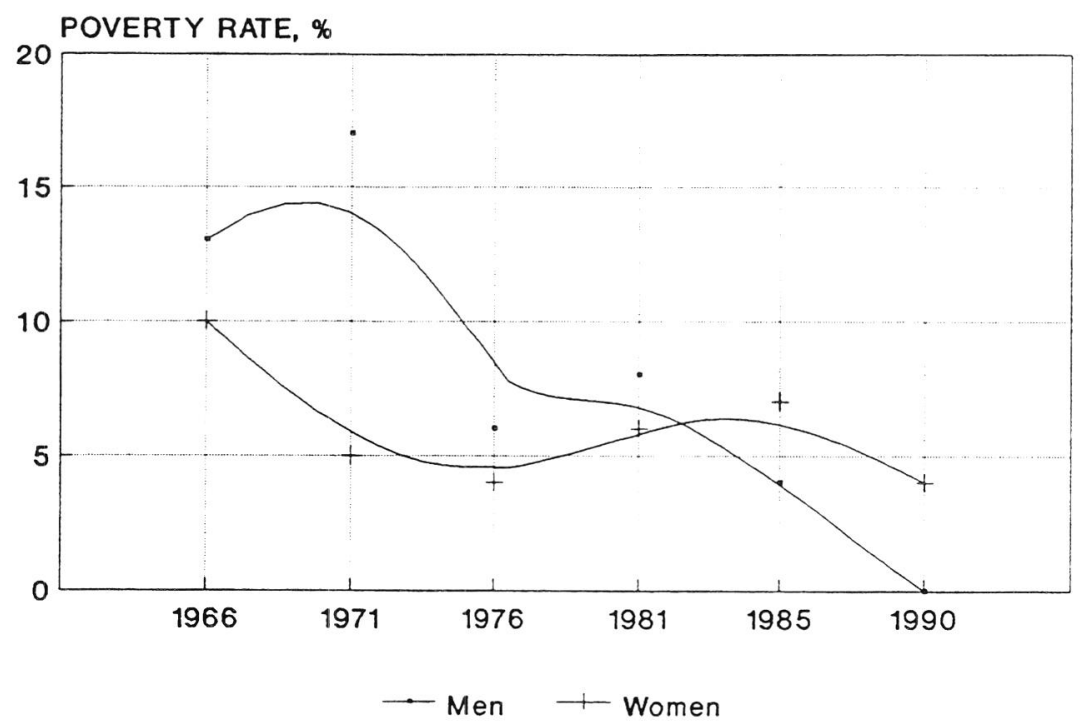


Since our data are based on household income, we cannot adequately evaluate individual pension income. The only way to estimate differences in poverty rate by gender from these data is to look at elderly persons living alone, as has been done in Figure 8. According to this figure, the poverty rate among elderly men seems to have been somewhat higher up to the mid-1980s, whereafter the picture is reversed. Thus, in concordance with our hypothesis, the cuts in national pensions have had stronger impacts on the elderly women than men. Unfortunately, the sample of one-person elderly households is very small ( $\mathrm{n}<$ 100 ), which means that the differences are not statistically significant and are only indicative.

The main lesson to learn from the inspection above is as follows: the transformation of the Finnish pension regime from a marginal to the institutional model has considerably reduced the poverty rate among the elderly -- whether male or female. By 1990, the Finnish poor were not elderly and the Finnish elderly were not poor.

\section{Pension policy and income distribution}

In addition to combating poverty, an important task for pension policy is the reduction of inequality in the economic well-being of the elderly. In a similar way as in measuring poverty, there is no one best way to assess inequality, but various inequality indices may be used (for a discussion, see Nygård \& Sandström 1981; Jäntti 1993). A commonly-used measure is the squared coefficient of variation, CV ${ }^{2}$ (see e.g., Nygård and Sandström 1981, 406-407). Since it also has some useful decomposition properties, we have chosen to work with the $\mathrm{CV}^{2}$. This index can conveniently be decomposed into separate 
components to assess the quantitative importance of each income source in the income package (see the methodological appendix).

Developmental patterns from 1966 to 1990 in inequality among the elderly are displayed in Figure 9. Inequality in all age groups is greater in 1966 and 1971 than at the later points in time. With the exception of the age bracket of 50-54 years, the 1976 inequality line is above the lines for the eighties. According to the $\mathrm{CV}^{2}$, inequality further decreased during the 1980s. This is true especially with reference to the age groups over the normal pension age of 65 years. Data for the three latest observation years do not indicate major changes in inequality between the age brackets.

Figure 9. Income inequality in Finland among elderly age groups, 1966-1990.

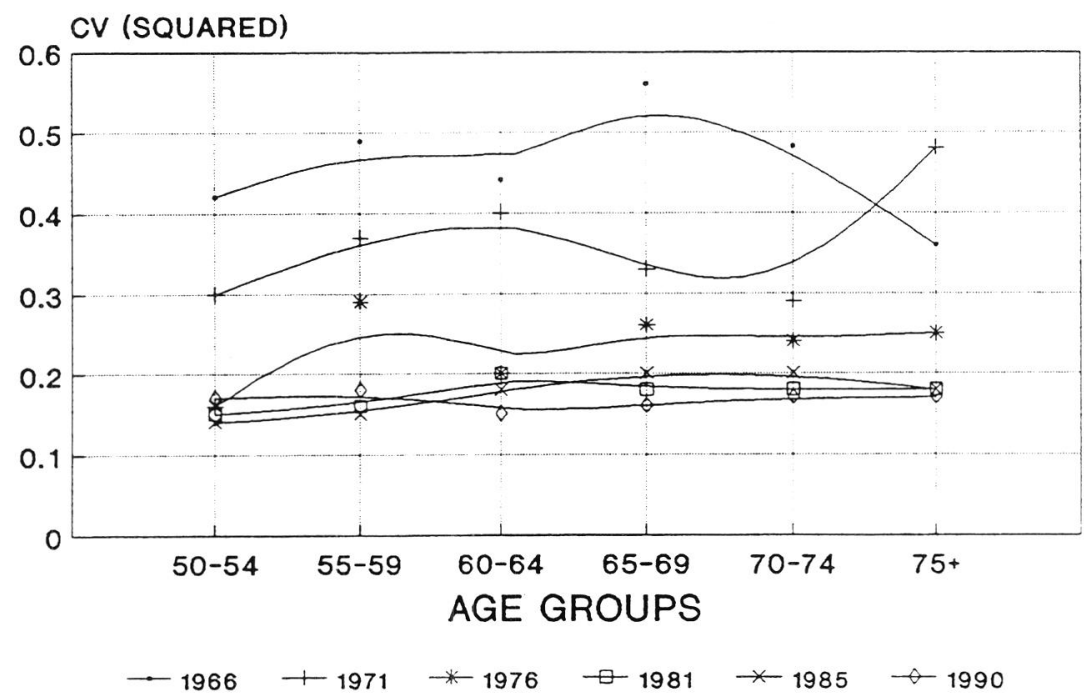

In the same vein as in old-age poverty, we are also interested in cohort effects. As can be seen in Figure 10, the two oldest cohorts form a distinct group, showing a higher degree of inequality than the subsequent cohorts. Inequality 
patterns among the other cohorts are almost identical, indicating that the development of pension rights has not essentially changed income distribution.

Figure 10. Inequality in Finland among different cohorts.

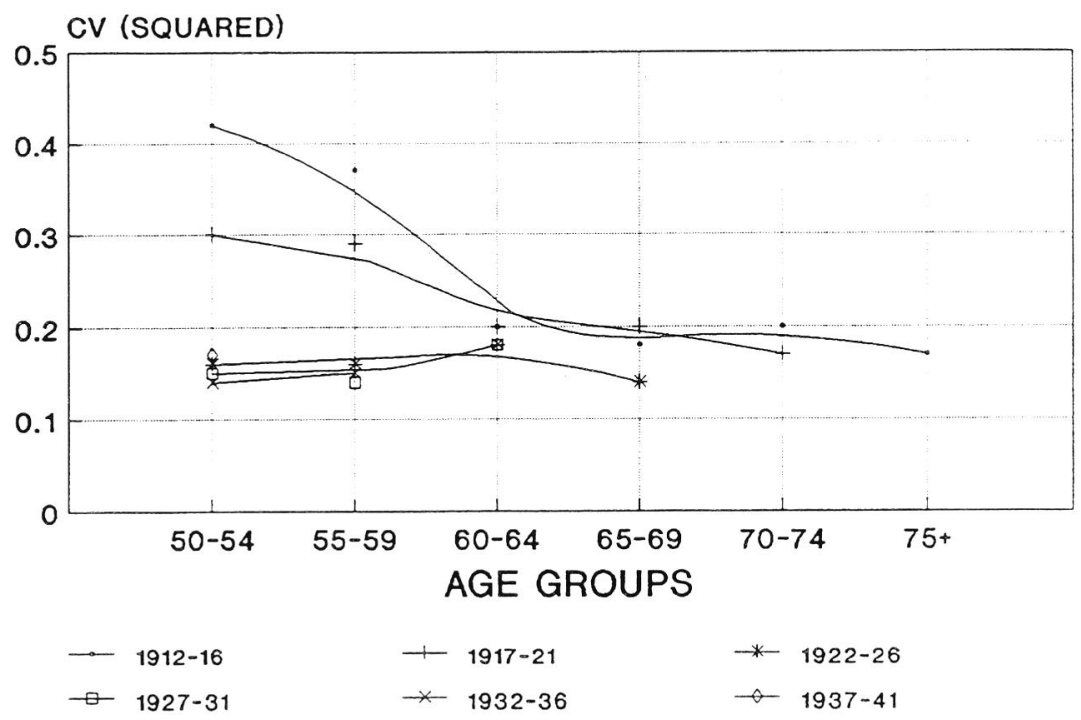

In addition to the overall trends in inequality, we have calculated separate $\mathrm{CV}^{2}$ values for each component in the income package, in order to differentiate the distributional profiles of the various income components. The results are shown in Table 2. Inequality both of disposable income and of gross income has steadily decreased -- the only exception is a slight increase from 1981 to 1985. As regards the statutory pension programs, the distribution of national pensions is by now the most even, followed by the private-sector employment-related pensions (TEL) and the public-sector pensions (VEL/KVTEL). The distributional profiles of the non-statutory components of the income package (work income, income from self employment, capital income and occupational pensions) are the most unequal. 
The last column in Table 2 displays the annualized percentage changes from 1966 to 1990 in each component. It can be seen that the most dramatic change has taken place in the TEL pensions. In 1966, income from this source was clearly biased in favor of high-income earners, whereas by 1990 TEL was one of the most egalitarian schemes -- second only to national pensions. A reverse trend is visible in voluntary occupational pensions, which display the most uneven distributional profile, manifesting the highly exclusive character of these benefits. These results are consequences of two interwoven processes. First, in the sixties TEL benefits for the majority of blue-collar workers were meager, whereas many white-collar workers with long employment in the same enterprise were entitled to better pensions ${ }^{3}$. Thus, the early TEL benefits shared similar traits with the present private occupational pensions. Second, the gradual improvement of the TEL system has crowded-out the majority of older occupational arrangements (as indicated by Figures 3 and 4), and by now, the few existing occupational schemes are both very limited in their coverage and generous in design, which inevitably leads to an unequal distribution of benefits.

\footnotetext{
${ }^{3}$ This was mainly due to the special rules regulating the computation of the pension amount: 1) every year in employment from 1962 onwards accumulated pension rights by 1 percent (since 1975 by 1.5 percent); 2) employment history prior to 1962 was taken into consideration only if the claimant had worked continuously in the same enterprise. Since white collar-workers tend to have permanent and long-term employment contracts, in contrast to the situation of blue-collar workers, the middle class benefitted from the calculation rules, which were not that favorable to the traditional working class.
} 
Table 2. Inequality of the components of the income package of the elderly (65+ years) in Finland 1966-1990, coefficient of variation (squared) and annualized percentage change.

\begin{tabular}{|c|c|c|c|c|c|c|c|}
\hline & 1966 & 1971 & 1976 & 1981 & 1985 & 1990 & $\begin{array}{r}\text { Change } \\
1966-90\end{array}$ \\
\hline Disposable income & 0.57 & 0.37 & 0.24 & 0.20 & 0.21 & 0.16 & -4.7 \\
\hline Gross income & 0.96 & 0.58 & 0.52 & 0.39 & 0.42 & 0.27 & -4.7 \\
\hline \multicolumn{8}{|l|}{ Statutory social security } \\
\hline National pensions & 0.48 & 0.37 & 0.37 & 0.36 & 0.29 & 0.32 & -1.7 \\
\hline Private sector statutory & 30.09 & 11.93 & 4.78 & 2.88 & 2.84 & 1.19 & -7.7 \\
\hline Public sector statutory & 9.87 & 10.05 & 8.61 & 5.30 & 5.19 & 3.49 & -4.0 \\
\hline All statutory pensions & 1.00 & 0.94 & 0.89 & 0.46 & 0.46 & 0.27 & -4.8 \\
\hline Other transfers 6.14 & 3.00 & 2.84 & 2.67 & 2.91 & 2.82 & -3.1 & \\
\hline Occupational pensions & 17.25 & 13.47 & 45.81 & 124.43 & 67.86 & 84.27 & 5.5 \\
\hline Earnings & 6.40 & 4.42 & 5.62 & 9.62 & 14.15 & 17.44 & 3.9 \\
\hline Self-employment & 7.62 & 4.88 & 7.76 & 9.51 & 14.17 & 18.01 & 3.4 \\
\hline Capital income & 15.48 & 9.13 & 17.04 & 11.19 & 11.73 & 6.25 & -3.5 \\
\hline
\end{tabular}

In order to get a fuller picture of the distributional effects of the components in the income package, we have calculated the relative contribution of each component to overall income inequality, by weighting each component's redistributive effect by the component's relative share in the income package (see the methodological Appendix). The results are presented in Figure 11. Positive values indicate that the component in question positively contributes to inequality (increases inequality) and negative values pertain to negative contributions (diminishing inequality). 
Figure 11. Contribution to inequality of disposable income.

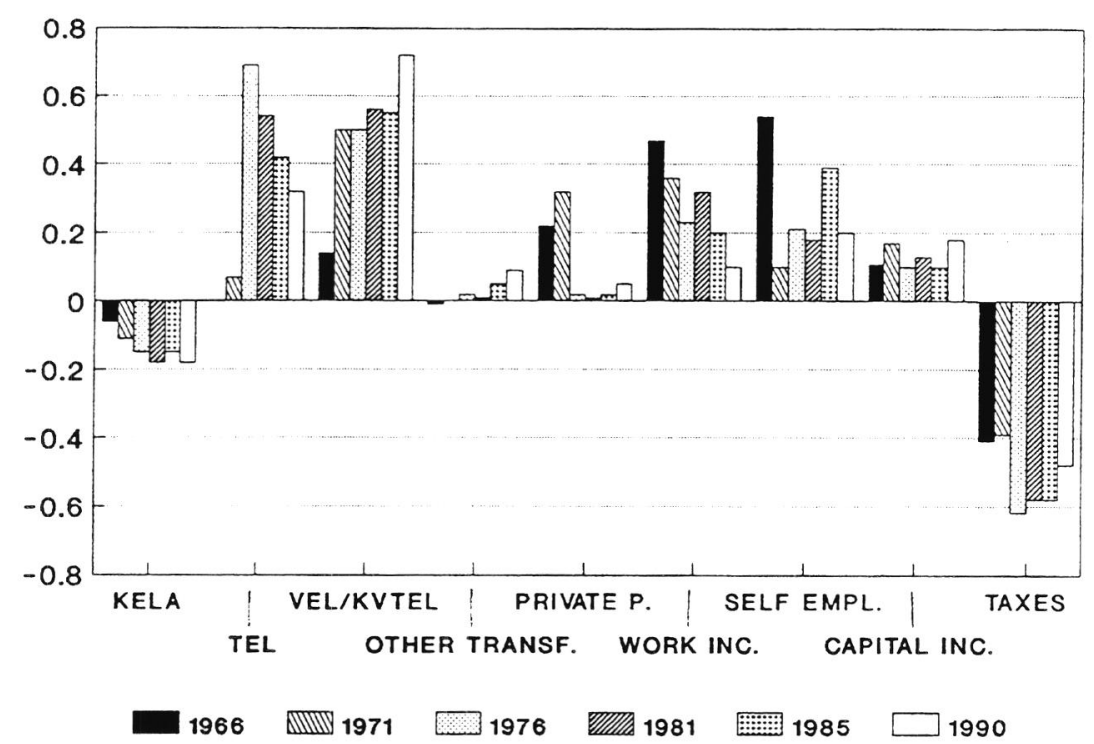

Two of the components of the income package are redistributive: national pensions and taxes. The redistributive effect of national pensions continuously increased from 1966 to 1981, but since then the redistribution through basic pensions has stagnated to the 1981 level. Taxes have strong redistributive effects, but since the mid-1970s these effects have diminished. In tandem with the shrinking role of private occupational pensions and earnings as a source of income for the elderly, the contribution from these components to total inequality have declined. The patterns for the two statutory earnings-related pension schemes are interesting. The contribution to inequality from the public-sector employees' schemes (VEL/KVTEL) has constantly increased over time, while the private-sector schemes (TEL/LEL) show a quite different pattern. At first the contribution dramatically rose, but after 1976 there is a continual decline, which indicates that the employment-related pension benefits are more equally distributed over employment categories than they used to be. 


\section{Discussion}

In the beginning of the 1960 s, the level of Finnish social protection was comparatively speaking very low. The benefit level was inadequate and the number of persons covered by social insurance was limited. Means-testing conditioned eligibility for statutory old-age pensions. With the exception of some categories of white-collar workers, employees were without incomegraduated pensions. In social policy terms, Finland belonged to the group of countries with marginal social policy.

From the early 1960s, the character of the Finnish welfare state rapidly changed. The basic pensions were improved and the implementation of the universal income-related superannuation scheme considerably improved the economic well-being of the elderly. The Finnish pension regime shifted from marginalism to institutionalism.

Our analysis of poverty and income distribution shows that the shift of the pension regime had a profound impact on the economic well-being of the Finnish elderly. Up to the mid-1960s, poverty was a persistent problem among the elderly, but by 1990 the old-age poverty rate in Finland was one of the lowest among the OECD countries. Thus, the shift towards the institutional social policy model has substantially reduced old-age poverty. In a similar way, overall inequality among the elderly rapidly decreased from 1966 to 1976, although since then no major changes have taken place.

The results above clearly indicate that statutory universal programs in Finland have equalizing effects, despite the fact that there is a certain degree of built-in inequality in the schemes in the form of earnings-relatedness. In Finland, the statutory, completely earnings-related pension schemes have gradually 
crowded-out the more regressive components of the income package. Our results show that the non-statutory components are strongly biased in favor of high-income earners, and the expansion in those components would increase inequality among the elderly (cf., Korpi 1992). It should be remembered that in principle, the extension of coverage would step by step diminish the inequalizing effect of the private occupational schemes, precisely in the same way as happened in the context of TEL pensions. However, this option would materialize only on condition that the coverage of occupational pension is virtually universal, or at least very wide, and that the schemes treat all employment categories similarly. This is hardly the case. Empirical evidence from other countries shows that occupational benefits are directed to the middle rather than to the working class and to men rather than women, and to those in strong labor market positions rather than to those whose status is more marginal (e.g., Taylor-Gooby 1991, 26-51).

At present, there are severe pressures on the Finnish pension model: the greying of the population, improving pension levels, and the increasing numbers of pensioners are creating pressure to increase employers' and employees' contributions, while the deep economic recession has led to intolerable level of unemployment and deteriorated the balance in the government budget, which thus sets more stringent economic limits to the financing of pensions and other public expenditure. In the early 1990s, the Center-Conservative government introduced a number of austerity measures which included freezing the indexation of pensions, increasing the pension age in early retirement plans, and introducing special taxes and social security contributions for pension recipients. Also direct cuts have been proposed in statutory pension benefits: the universal national pension should not be paid to those receiving employment related pensions; the target level in statutory income-related pensions should be lowered from 60 percent to 55 or even to 
50 percent of income; income for pension purposes should be calculated from income for the last ten years or lifetime income instead of the present base of the four last years in employment; indexation of pensions should be changed so that benefits would no longer rise to match subsequent increases in wages. Some politicians have proposed a shift away from income-graduated statutory pensions back to flat-rate pensions. The most radical suggestions argue that statutory pensions should be targeted at the most needy, while the rest of the population should contract individual pension policies or negotiate with their employer on occupational labor market benefits. In sum, a shift from institutionalism back to marginalism is proposed. Thus, there is a fear that this shift would gradually result in the reverse of the greater social equality produced by the transformation from marginalism to institutionalism. 


\section{Bibliography}

Alcock, Pete (1993): Understanding Poverty. Macmillan: London.

Castles, Francis \& Deborah Mitchell (1990): Three Worlds of Welfare Capitalism or Four. Canberra: The Australian National University, Discussion Paper No. 21.

Esping-Andersen, Gosta (1990): The Three Worlds of Welfare Capitalism. Oxford: Polity Press.

Fritzell, Johan (1991): Icke av marknaden allena: Inkomstfördelningen i Sverige. Stockholm: Swedish Institute for Social Research.

Griffin, Tom (ed.) (1992): Social Trends 22. London: HMSO.

Hagenaars, Jaques (1990): Categorical Longitudinal Data: Log-Linear, Panel, Trend, and Cohort Analysis. London: Sage.

Hedström, Peter \& Stein Ringen (1990): 'Age and Income in Contemporary Society.' in Timothy Smeeding, Michael O'Higgins \& Lee Rainwater (eds.): Poverty, Inequality and Income Distribution in Comparative Perspective. New York: Harvester Wheatsheaf, pp. 77-104.

Jäntti, Markus (1993): Essays on Income Distribution. Åbo: Åbo Akademi University Press.

Kangas, Olli (1994): 'The merging of welfare state models? Past and present trends in Finnish and Swedish social policy.' Journal of European Social Policy, Vol 4, No 2, pp. 79-94.

Kangas, Olli \& Joakim Palme (1992): 'The Private-Public Mix in Pension Policy.' in Jon Eivind Kolber (ed.): The Study of Welfare Regimes. New York: M.E. Sharpe, pp. 199-237.

Korpi, Walter (1980): 'Social Policy and Distributional Conflict in the Capitalist Democracies.' West European Politics, Vol. 3, No 3, pp. 294-316.

Korpi, Walter (1992): Welfare state development in Europe since 1930. Dublin: The Economic and Social Research Institute. 
Korpi, Walter \& Joakim Palme (1994): The strategy of equality and the paradox of redistribution. Paper presented at the World Congress of the International Sociological Association, Research Committee 19. Bielefeld, July 1994.

Kuhnle, Stein \& Per Selle (1990): "Meeting Needs in a Welfare State: Relations Between Government and Voluntary Organizations in Norway." in Alan Ware \& Robert Goodin (eds.): "Needs and Welfare". London: Sage, pp. 165-184.

Mitchell, Deborah (1991): Income Transfers in Ten Welfare States. Aldershot: Avebury.

Mishra, Ramesh (1981): Society and Social Policy: Theories and Perspectives of Welfare. London: Macmillan.

Nygård, Fredrik \& Arne Sandström (1981): Measuring income inequality. Stockholm: Almqvist \& Wicksell.

Palme, Joakim (1990a): Pension Rights in Welfare Capitalism. Stockholm: Swedish Institute for Social Research.

Palme, Joakim (1990b): 'Models of old-age pensions.' in Alan Ware \& Robert E. Goodin (eds.): Needs and Welfare. London: Sage, pp. 104-125.

Rainwater, Lee, Martin Rein \& Joseph Schwartz (1986): Income Packaging in the Welfare State. A Comparative Study of Family Income. Oxford: Clarendon Press.

Ringen, Stein (1987): The Possibility of Politics. A Study in the Political Economy of the Welfare State. Oxford: Clarendon Press.

Ritakallio Veli-Matti (1994a): Finnish Poverty: A Cross-National Comparison. Luxembourg Income Study, Working Paper 119.

Ritakallio, Veli-Matti (1994b): Köyhyys Suomessa 1981-1990 (Poverty in Finland 1981-1990; with English summary). Helsinki: Stakes.

Salminen, Kari (1993): Pension Schemes in the Making: a Comparative Study of the Scandinavian Countries. Helsinki: the Central Pension Security Institution.

SCIP: Social Citizenship Indicators Project. A database compiled at the Swedish Institute for Social Research, University of Stockholm. 
Smeeding, Timothy, Richard Hauser, Lee Rainwater, Martin Rein \& Gaston Schaber (1985): Poverty in the Major Industrial Countries.

Luxembourg Income Study, Working Paper 2.

Smeeding, Timothy, Michael O'Higgins \& Lee Rainwater (1990): Poverty, Inequality and Income Distribution in Comparative Perspective. New York: Harvester Wheatsheaf.

Taylor-Gooby, Peter (1991): Social Change, Social Welfare and Social Science. London: Harvester Wheatsheaf.

Titmuss, Richard (1974): Social Policy: Introduction. London: Allen \& Unwin.

Uusitalo, Hannu (1989): Income Distribution in Finland. Helsinki: Central Statistical Office, Studies 148.

Whiteford, Peter (1993): The Concept of income in international comparative research. Paper presented at the Conference on Comparative Research on Welfare States in Transition. International Sociological Association, Research Committee 19. Oxford, September 1993. 


\section{Methodological appendix}

There is no best way of decomposing income inequality indices by income source, just as there is no one best income inequality index. A commonly used measure is the squared coefficient of variation, $\mathrm{CV}^{2}$ (see e.g., Nygård and Sandström 1981, 406-407). Since it also has some convenient decomposition properties, We choose to work with the $\mathrm{CV}^{2}$. This index can conveniently be decomposed into separate components to assess the quantitative importance of each income source The $\mathrm{CV}^{2}$ can be written

$$
C V^{2}=\sum_{k} \frac{\mu_{k}^{2}}{\mu^{2}} C V_{k}^{2}+\sum_{j \neq k} \sum_{k} \frac{\mu_{j}}{\mu} \frac{\mu_{k}}{\mu} \rho_{j k} C V_{j} C V_{k}
$$

where $\mu_{\mathrm{k}}$ and $\mu$ are the means of the $k$ th income component and disposable income, respectively, $C V_{\mathrm{k}}$ and $C V$ are the coefficients of variation and $\rho_{\mathrm{k}}$ is the correlation between the $j$ th and the $k$ th component. The square of the ratio of the mean of the $k$ th component to the overall mean can be interpreted as the weight on the income inequality of the $k$ th component. One possibility to assess the contribution of the income components to changing inequality is to change the weights, the coefficients of variation and the correlations sequentially, and to register the percentage change in overall inequality at each stage. An alternative is to change the three sets of parameters -- the means, the variances and the correlations between different income components -- sequentially.

The problem with these approaches is that the magnitude of each effect depends on the order in which the parameters are changed. This follows from the fact that changing the parameters sequentially creates different income distributions. Other approaches are available. In this chapter we decompose the $\mathrm{CV}^{2}$ into a sum of $k$ terms:

$$
C V^{2}=\sum_{k} \frac{\operatorname{Cov}\left(y_{k}, y\right)}{\mu^{2}}=\sum_{k} \rho_{k} C V_{k} C V \frac{\mu_{k}}{\mu}=\sum_{k} S_{k}
$$

where $\rho k$ is the correlation coefficient between $\mathrm{y}_{\mathrm{k}}$, the $k$ th component and $y$, disposable income. Dividing through by $\mathrm{CV}^{2}$, We get the relative contribution of each $k$ components, $\mathrm{s}_{\mathrm{k}}$, to overall income inequality: 


$$
\sum_{k} \frac{S_{k}}{C V^{2}}=\sum_{k} s_{k} \equiv 1 .
$$

These relative contributions can then be compared across years to assess the importance of each income component. $S_{k}$ and $s_{k}$ are measures of the importance of a component for total $\mathrm{CV}^{2}$. Looking at how these terms change reveals how the contribution of each separate source of income changes in total inequality. (See Jenkins (1992) and Shorrocks (1982).

We are also interested in another type of question, namely: What was the share of each component in the change in $\mathrm{CV}^{2}$ from the first year we have data, $\mathrm{t}_{1}$, to the second year, $\mathrm{t}_{2}$ ? This can be studied by decomposing the change in $\mathrm{CV}^{2}$ into separate parts. Define the annualized change as

$$
\% \Delta=100 \times \frac{C V_{t 2}^{2}-C V_{t 1}^{2}}{C V_{t 1}^{2}} \cdot \frac{1}{\tau},
$$

where $\tau=t 2-t 1$. This can be decomposed into a sum of the $k$ parts; in order to study $\% \Delta$ in terms of the percentage change in each components contribution, $\% \Delta \mathrm{S} k$, write

$$
\begin{aligned}
\% \Delta & =\sum_{k} 100 \times \frac{S_{k, t 2}-S_{k, t 1}}{S_{k, t 1}} \cdot \frac{S_{k, t 1}}{C V_{t 1}^{2}} \cdot \frac{1}{\tau} \\
& =\sum_{k} \% \Delta S_{k} \cdot s_{k, t 1},
\end{aligned}
$$

giving the contribution of each component to total change. The first part in the product is the annualized percentage change in the contribution and the second part is the average relative contribution of the $k$ th income component. Thus, the change in $\mathrm{CV}^{2}$ is expressed as the percentage change of each components contribution weighted by the average relative contribution of that component ${ }^{1}$. growth.

${ }^{1}$ Note that the procedure assumes constant growth over time instead of, e.g., compound 


\section{Eläketurvakeskuksen tutkimuksia}

1990:1. Janhunen Jouko. ELÄKEJÄRJESTELMÄT TEOLLISUUSMAISSA 1990, $232 \mathrm{~s}$.

1991:1. Gould Raija - Takala Mervi - Lundqvist Bo. TYÖ VAI ELÄKE. Yksilöllisellä varhaiseläkkeellä olevien ja työssä käyvien vertailu, $62 \mathrm{~s}$.

1991:2 Forss Simo - Tuominen Kristiina. NUORENA ELÄKKEELLE. YVEeläkeläisen näkökulma, $55 \mathrm{~s}$.

1991:3 Kannisto Jari. YKSILÖLLISELLE VARHAISELÄKKEELLE SIIRTYNEIDEN TYÖHISTORIA. TEL:n piiristä yksilölliselle varhaiseläkkeelle 1986-1988 siirtyneiden työhistoria yksityisellä sektorilla, $48 \mathrm{~s}$.

1992:1 Gould Raija - Takala Mervi - Lundqvist Bo. VARHAISELÄKKEELLE HAKEUTUMINEN JA SEN VAIHTOEHDOT, $41 \mathrm{~s}$.

1992:2 Karisalmi Seppo. KANSALAISET, SOSIAALITURVA JA TYÖELÄ$\mathrm{KE}, 62 \mathrm{~s}$.

1992:3 Hyrkkänen Raili. PALKATON KOTITYÖ LESKEN TYÖURASSA JA ELÄKETURVASSA, $253 \mathrm{~s}$.

1992:4 Salminen Kari - Vanamo Jussi. MEDBORGARSKAP OCH ARBETSPRESTATION. KONFRONTATION ELLER KOMBINATION, $28 \mathrm{~s}$.

1993:1 Forss Simo - Luoma-aho Erkki - Ruuska Tauno. AJOISSA KUNTOON. Varhaiskuntoutuksen kokeilu työeläkejärjestelmässä, $60 \mathrm{~s}$.

1993:2 Salminen Kari. PENSION SCHEMES IN THE MAKING. A Comparative Study of the Scandinavian Countries, $410 \mathrm{~s}$.

1993:3 Kannisto Jari. YKSITYISEN SEKTORIN TYÖURAT JA ELÄKEPROSENTIT VUONNA 1990, $38 \mathrm{~s}$.

1993:4 Karisalmi Seppo. ENNAKKOTIETOJA REKISTERIOTETUTKIMUKSESTA, $140 \mathrm{~s}$

1993:5 Niemelä Heikki - Salminen Kari - Vanamo Jussi. PENSIONSSYSTEMEN I NORDEN - TOTALREFORM ELLER STEGVIS FÖRNYEL$\mathrm{SE}, 45 \mathrm{~s}$.

1994:1 Tuominen Eila. ELÄMÄNMUUTOS JA MUUTOKSEN HALLINTA, $411 \mathrm{~s}$.

1994:2 Forss Simo - Karjalainen Pirkko - Tuominen Kristiina. ELÄKELÄISET JA VANHUSTEN AVUNTARVE. Tutkimuksen väliraportti, $42 \mathrm{~s}$.

1994:3 Gould Raija. TYÖELÄMÄ TAKANAPÄIN? Tutkimus ikääntyneiden työntekijöiden työssä pysymisestä vuosina 1990-1993, $56 \mathrm{~s}$. 
1994:4 Takala Mervi. OSA-AIKAELÄKE. Katsaus osa-aikaeläkettä koskeviin tilasto- ja tutkimustietoihin, $27 \mathrm{~s}$.

1994:5 Karisalmi Seppo. TYÖNTEKIJÄN REKISTERIOTE JA TYÖELÄKESANOMAN VASTAANOTTO, $106 \mathrm{~s}$.

1995:1 Hyrkkänen Raili. YRITTÄJIEN ELÄKETURVA JA SUKUPOLVENVAIHDOKSET, $104 \mathrm{~s}$.

1995:2 Lundqvist Bo - Salminen Kari - Tuominen Eila - Vanamo Jussi. HYVINVOINTIVALTIO, ELÄKETURVA JA KANSAINVÄLISTYMISEN HAASTEET, $200 \mathrm{~s}$.

1995:3 Forss Simo - Karjalainen Pirkko - Tuominen Kristiina. MISTÄ APUA VANHANA? Tutkimus vanhusten avuntarpeesta ja eläkeläisten vapaaehtoistyöstä, $136 \mathrm{~s}$.

1995:4 Gould Raija. MTTÄ ELÄKEHYLKÄYKSEN JÄLKEEN. Tutkimus yksilöllisen varhaiseläkkeen hylkäyspäätöksen saaneiden palkansaajien myöhemmistä vaiheista, $60 \mathrm{~s}$. 
"From marginalism to institutionalism" offers a longitudinal scrutiny of the development of pension policy in Finland and evaluates the impacts that the shift from 'marginal' social policy to the 'institutional' welfare state imposed on economic wellbeing and income distribution among the elderly. 